\title{
A Cooperative Model for Preserving Historical Television News Content
}

\section{By Morgan Gieringer}

ABSTRACT: The University of North Texas (UNT) and the Dallas-Fort Worth (Texas) affiliate station of the National Broadcasting Company (NBC 5/KXAS-TV) have partnered to preserve the archival programming content of the oldest television news station in Texas. This article addresses the partnership of the archives and the news station to create a fully digitally accessible archive, as well as the challenges of large-scale preservation and digitization of audiovisual materials. Using a custodial partnership model, the archives and the news station have leveraged their own unique talents and abilities to make significant progress toward the goal of digitizing this historic collection. This article highlights the progress made over the first five years of the partnership and the aspects of the partnership that have made the project successful.

\section{Introduction}

The archival profession must begin to confront the many challenges inherent in the large-scale preservation of twentieth-century audiovisual resources. A significant portion of our shared cultural heritage, including historical television news recordings, is at risk due to complicated copyright issues, degradation of the original media, the cost involved in digitizing audiovisual resources, and the difficulty of preserving highresolution digital video files. The NBC 5/KXAS-TV project highlights the extreme difficulties inherent in preserving twentieth-century television news content, but also demonstrates the cultural significance and importance of preserving this content for future generations. Unfortunately, a large amount of twentieth-century broadcast news content has already been lost, as television news reporters and production staff focus on the here and now, and yesterday's news was only intended to be recorded and preserved for a short period of time. In many cases, neglected news collections have reached a point of no return in their deterioration, and silent $16 \mathrm{~mm}$ news film exists for which no accompanying scripts or indexes were preserved, making the content so opaque in its lack of descriptive metadata as to render it virtually useless. Other major television news collections may be found in the holdings of the University of California, Los Angeles Film and Television Archive; the Lynn and Louis Wolfson II Florida Moving Image Archive at Miami Dade College; the WGBH Media Library and Archive in Boston, Massachusetts; and the University of Baltimore, among other institutions. While many of these institutions hold one or even multiple television news collections, access is limited due to factors such as minimal description of collections, limited reformatting efforts, and/or unclear copyright status or licensing rights. The overwhelming costs associated with processing, describing, and digitizing large audiovisual collections exacerbated these challenges. 
Cooperation between heritage institutions and content creators, facilitated by a longterm partnership agreement, is the key to overcoming these significant challenges. The University of North Texas (UNT) and the Dallas-Fort Worth (Texas) affiliate station of the National Broadcasting Company (NBC 5/KXAS-TV) have partnered to preserve the content of the oldest television news station in Texas. This unique partnership will not only preserve over 60 years of television news content through the digitization of original $16 \mathrm{~mm}$ film and video, it will also result in free public access to the digitized content online. This article will explain this partnership from the perspective of both the library and the television news station, and it will provide possible solutions to the issues of copyright, funding, and access to audiovisual collections. Examples from the UNT-NBC 5/KXAS-TV-TV partnership will illustrate the crucial need to preserve audiovisual collections and the challenges facing institutions preserving large-scale audiovisual collections. Finally, this article introduces the custodial partnership model-a new paradigm for potential partnerships between heritage institutions and content creators-as well as recommendations for future modes of cooperation.

\section{NBC 5/KXAS-TV (WBAP-TV) History}

The rise of broadcast television news in the 1940s was a natural extension of the capabilities built during the war years by the major radio broadcast networks. Surveys conducted at the end of World War II revealed that radio had surpassed print journalism to become the main source of news for many Americans, and the public well respected radio journalists such as Edward R. Murrow. ${ }^{1}$ Of the four major networks at the time, NBC (National Broadcasting Company) and CBS (Columbia Broadcasting System) were best situated to aggressively seek out local radio stations around the country that were moving into the new field of television to join them as affiliates. In 1946, publisher Amon G. Carter filed permits with the Federal Communications Commission for construction of a television station in Fort Worth, Texas. Carter, already a legend in the publishing world, had been successfully operating the Fort Worth Star-Telegram newspaper since 1909 and a major NBC-affiliated radio station, WBAP, since $1922 .{ }^{2}$ His new television station, WBAP-TV, also an NBC affiliate, aired its first broadcast on September 27, 1948. WBAP-TV was the first television station in Texas and the only television station in the entire southwestern United States. ${ }^{3}$

For over 65 years, the station-renamed NBC 5/KXAS-TV in 1974 following its sale to LIN broadcasting - continued to broadcast from its original location in Fort Worth. In 2012, the station began construction of a new $\$ 16$ million facility centrally located in the Dallas-Fort Worth metroplex, from which it began broadcasting in early $2014 .^{4}$ News programming at NBC 5/KXAS-TV has grown over the years from a daily 15 -minute newsreel in the 1950 s to multiple daily news broadcasts by the 1970 s. The station continued to be a leader in local television news by becoming the first station in Texas to feature all-color news film in 1966 and was the first station in the country to produce a monthly "news magazine" featuring in-depth, documentary-style reporting. 
The real innovation of WBAP-TV and later NBC 5/KXAS-TV was in the high-quality content of their news reporting. During the 1950s and 1960s, most local affiliate stations focused on live entertainment programming featuring dancers or musical performers that did not require an investment in costly film technology. Furthermore, many local affiliates believed that they would only be duplicating the efforts of radio and newspaper journalists by creating news programming, so they simply relied on summaries of wire reports to provide viewers with the news. ${ }^{5}$ In contrast, WBAP-TV featured news reporting from across the Dallas-Fort Worth metro area ranging from crime, politics, and current events to public interest and even novelty reporting. News film from WBAP-TV was broadcast nightly as early as 1951 (and perhaps earlier, although no footage from the years 1948 to 1950 was retained) in a 15-minute program called The Texas News. This early news format featured five to eight short news segments with live, in-studio narration read from a prepared script. Most of the footage itself was silent, as sound was only recorded on film during brief interviews. It is estimated that by 1952, 32 percent of American households had a television set. ${ }^{6}$ This means that in a metroplex of over 1.1 million people at that time, as many as 350,000 people could have been tuning in to watch the nightly local news. Evidence also suggests that news film produced by KXAS-TV was selectively compiled and distributed as newsreels throughout the state. An example of a KXAS-TV newsreel located in the J. Fred MacDonald Newsreel Collection at the Library of Congress features several stories from November 1954 with narration and music added to the film that do not appear in the regular news broadcast. ${ }^{7}$

A typical 15-minute newsreel from the earliest existing footage in the WBAP-TV collection contains coverage reminiscent of what today might be called "hyperlocal" news. College and high school sports, meetings of fraternal and service organizations, and city council meetings were frequently covered. These broadcasts also included public interest stories, such as a memorable segment from 1951 featuring dramatic footage of a horse being lifted from an abandoned well. The horse, named Major, was returned to pasture unharmed. ${ }^{8}$ Although news coverage may have focused on local news events, it would be a mistake to assume that this coverage has no broader significance. In the decade following World War II, the Dallas-Fort Worth metroplex experienced tremendous population growth fueled by the availability of thousands of jobs in the area. This growth, however, also placed a strain on many of the residents of the Dallas-Fort Worth area who suddenly felt the encroachment of "big-city problems" into their small-town lives. Second, as one of the largest metropolitan areas in the county, the experiences of people living there reflected the issues that faced the nation at large, including the civil rights struggles of the 1950s and 1960s.

\section{NBC 5/KXAS-TV (WBAP-TV) Partnership with University of North Texas}

In 2014, UNT entered into an agreement with local television station NBC 5/KXASTV (formerly WBAP-TV) to permanently house over 50 years of historical television news footage along with accompanying broadcast scripts, photographs, reference files, 
and log books, in the Special Collections department of UNT Libraries. This massive collection is the single largest physical collection held by the libraries and contains a variety of film and video formats that reflect the evolution of recording technology employed by the station over the years. Table 1 contains a breakdown of the content types and quantities found within each series of the news archive.

Table 1: NBC5/KXAS Collection Contents

\begin{tabular}{|l|l|l|}
\hline Series & Format & Quantity \\
\hline Daily news film, 1951-1979 & 16mm film & 10,000 reels \\
\hline Archive tapes, 1976-1986 & 3/4 inch U-matic video & 2,000 tapes \\
\hline Archive tapes, 1986-1995 & Betacam SP video & 7,000 tapes \\
\hline Archive tapes, 1995-2012 & DVC Pro video & 4,000 tapes \\
\hline Broadcast scripts, 1951-1979 & Paper & 219,000 pages \\
\hline Daily log books, 1979-2012 & Paper & 22 volumes \\
\hline Still photography, 1948-1970 & Slides, negatives, photo prints & 5,000 images \\
\hline $\begin{array}{l}\text { PSAs, local advertising, reference } \\
\text { files, miscellaneous }\end{array}$ & Film and video, all formats & 500 items \\
\hline
\end{tabular}

The impending relocation of the television station from its original broadcast station in Fort Worth to a new broadcast facility spurred the donation of the NBC 5/KXASTV collection to UNT. Station executives decided that the massive archive, which had slowly accumulated in the basement since the station went on air in 1948, would not be transferred to the new facility. NBC 5/KXAS-TV reached out to archivists and librarians at UNT, and, over a period of several months, the two parties drafted a written agreement that addressed the needs of both the donor and the repository, as well as the special challenges inherent in preserving a large, primarily audiovisual collection. It was clear from the beginning that a traditional custodial agreement would not sufficiently address these needs; therefore, an agreement based on a partnership model was developed to allow physical custody and responsibility for permanent care of the collection to be transferred to UNT, while placing equal responsibility for fund-raising and promotion on both parties. The partnership model borrows elements from both the traditional custodial model and the newer postcustodial model, while emphasizing the need for ongoing cooperation between partners. For example, while physical ownership transfers from the donor to the repository, mirroring a traditional custodial agreement, an emphasis on digitization for public access to the collection mirrors a postcustodial agreement.

The most innovative aspect of the partnership agreement is that it also provides a clear outline for the ongoing participation of the donor in activities related to the collection and holds both parties accountable for participating in work necessary to meet the shared goal of preserving and making the collection publicly accessible through 
large-scale digitization. Although the terms of the agreement grant physical ownership of the archive to UNT, NBC 5/KXAS-TV retains ownership of the intellectual property rights for the collection. The agreement further outlines the methods for providing access to the collection: specific rights granted to UNT to digitize and make footage freely available online and the rights granted to UNT to license footage and collect fees for certain types of usage. Last, both institutions agreed to publicize the partnership and to cooperate to raise the funds necessary to provide free, public, digital access to the archive.

\section{Project Costs}

Costs for the project are divided into the following categories: audiovisual digitization, document and photograph digitization, student wages for metadata creation, and digital storage costs. Salaried staff time spent on the project and overhead costs, such as storage of the archive, are not included in the cost estimates. Digital storage proved to be the most difficult cost to estimate in this project. The repository requires two redundant copies of all digital content, doubling the storage cost, and, although the cost of digital storage is expected to continue to decrease over time, the sheer size of the predicted output is so large as to require a significant and ongoing financial investment. The typical preservation-quality file size for an hour of digitized film or video, in standard definition, is 100 gigabytes per hour. Therefore, the estimated storage requirement for the entire digitized film and video collection is between 1.87 and 2.2 petabytes (see Table 2).

Table 2: NBC 5/KXAS-TV Digitization Cost Estimates

\begin{tabular}{|l|l|l|}
\hline Description & Unit Cost & Total \\
\hline 10,000 reels $16 \mathrm{~mm}(50,000$ segments, 2,500 hours $)$ & $\$ 175 /$ reel & $\$ 1,750,000$ \\
\hline 13,000 video cassettes $(260,000$ segments, 18,000 hours) & $\$ 35 /$ tape & $\$ 455,000$ \\
\hline 219,000 pages $(50,000$ items $)$ & $\$ 0.30 /$ page & $\$ 65,700$ \\
\hline 360,000 metadata records & $\$ 1 /$ record & $\$ 360,000$ \\
\hline $2,050 \mathrm{~TB}$ storage (copy one) & $\$ 200 / \mathrm{TB}$ & $\$ 410,000$ \\
\hline $2,050 \mathrm{~TB}$ storage (copy two) & $\$ 200 / \mathrm{TB}$ & \\
\hline Total Estimated Cost & & $\$ 410,000$ \\
\hline
\end{tabular}

To date, over $\$ 500,000$ has been raised to support this project, including a $\$ 275,000$ donation from NBC 5/KXAS-TV. It is expected that additional funding will come from diverse sources including grants, foundation gifts, personal donations, and revenue from digitization and licensing fees. 


\section{Current State of Archival Materials and Access to Footage}

Access to the NBC 5/KXAS-TV collection is currently limited due to the fragility of the media on which much of the collection is recorded and the difficulty of navigating the indexing tools needed to locate footage. Due to serious preservation concerns with the original media, the recordings must be digitized prior to playback and users may not "screen" footage from the original film or video under any circumstances. For example, the Daily News $16 \mathrm{~mm}$ film reels were stored for over 50 years in the basement of the new studio. Each film reel contains multiple news stories that were aired together on a single day, and film from multiple camera operators was manually spliced together to create each reel. Following its use in the daily news broadcast, the film was stored wound on a core with a strip of masking tape to secure it. While the condition of the film itself is generally good, time must be spent with each reel to remove the tape, inspect and repair all the splices, clean dust and debris from film, and finally transfer the film from the core to a reel before it can be digitized.

Footage recorded on magnetic media is at a much greater risk of loss due to degradation of the original media, especially $3 / 4$-inch U-matic tape, which is subject to "sticky shed syndrome." Camera operators began the transition from film to video in 1976 and discontinued using $16 \mathrm{~mm}$ film by 1979 . Video footage was compiled and edited in two different locations, one in Dallas and the other in Fort Worth, by multiple editors in each location. Once the transition to video was completed, the daily news film reel was replaced by an archive tape system (also known as a log tape system) in which each produced segment was assigned an archival identifier and recorded onto an archive tape. The archival identifier, determined using the daily news log book, identifies the archive tape on which that segment can be found. The editor used a single archive tape until it was full, which means that each tape contains stories over a period of several days. To find all the footage from a single day's news broadcast usually requires pulling four or more archive tapes. Researchers hoping to find footage in the archive are directed to use daily broadcast scripts (for footage from 1951 to 1979) or daily log books (for footage from 1979 to 2012). The daily log books have been digitized and are available online in UNT's Portal to Texas History. ${ }^{9}$ Digitization of broadcast scripts began in 2015 and is still underway. ${ }^{10}$

\section{Licensing Archival News Footage}

Many uses of footage in the NBC 5/KXAS-TV collection do not require permission or a license. Users may stream digitized footage for personal or research purposes, for use in the classroom, or as part of educational materials, and footage may be freely shared online in personal blogs and social media. Usage beyond standard personal or educational, however, requires a license and may include a fee. For example, a filmmaker creating a documentary on the Dallas Cowboys cheerleaders would be required to license footage for use. NBC 5/KXAS-TV has granted UNT permission to license footage from the archive and collect licensing revenue. UNT Libraries does not publish a licensing rate card; instead, licensing requests are priced individually per second based 
on the content requested. Typical licensing fees range from $\$ 75$ to $\$ 90$ per second, and the library imposes a 30-second minimum per order. Revenue generated from licensing requests is added to a fund that supports continued digitization efforts until the collection has been fully digitized, at which point the revenue will be divided between UNT and KXAS-TV. Licensing activity has increased as content continues to be digitized and made publicly accessible through the Portal to Texas History. From September 2018 to August 2019, licensing revenue exceeded $\$ 100,000$. Prominent licensing projects during this period include BOSS: The Black Experience in Business, produced by Stanley Nelson for PBS; The Bush Years: Family, Duty, Power, a six-part series airing on CNN; The Last Defense, a limited-run series on ABC; and David Crosby: Remember My Name, a film produced by Cameron Crowe which premiered at the Sundance festival in January 2019.

Until a critical mass of content has been fully digitized, however, archival staff are somewhat limited in their capacity to fulfill licensing requests due to the difficulty inherent in conducting remote research in the collection and the time necessary to digitize analog media before it can be viewed. Filmmakers are generally working on a tight production schedule and are unable to visit the archive to conduct a search of the broadcast scripts to locate potentially relevant footage. Individuals also have difficulties searching broadcast log books, which use vague, sometimes inscrutable, indexing terms such as "robbery" or "meeting" to identify news stories. It can be difficult if not impossible to locate footage using these tools if the researcher does not know the exact air date of the relevant story. A researcher most likely will also have to pay a digitization fee to transfer the footage from the original media in addition to paying a licensing fee. This fee, and the time involved in research and digitization, are additional frustrations; however, it is expected that these issues will be resolved as more content is made readily available online.

\section{Pilot Project and Cooperative Publicity Plan}

At the suggestion of a faculty member in the UNT History Department, archivists selected six weeks of footage spanning August 1 through September 16, 1956, to digitize as a pilot project. This period saw several crucial developments in the ongoing civil rights struggles in north Texas, as housing desegregation protests occurred in Fort Worth, school desegregation lawsuits were underway in Dallas, and another incident, which came to be known as the Crisis in Mansfield, happened during this time. The attempt by four African American students to enroll in high school classes in the small north Texas community of Mansfield in the summer of 1956 touched off a significant episode in our nation's civil rights history. Although the school had been ordered to desegregate by the United States Court of Appeals for the Fifth Circuit, city officials and local law enforcement were determined to block the students' admission. Following their unsuccessful attempt to enroll, white community members created a dangerous and threatening atmosphere with demonstrations that culminated in the hanging of three effigies from nearby trees and even from the entryway of the high 
school itself. This incident, although rarely mentioned in history books, was a harbinger of what would come to be widespread failures to enforce desegregation orders in public schools throughout the country. ${ }^{11}$ Several days later, cameramen from WBAP-TV were in Mansfield to capture footage for a short segment about the demonstrations on their nightly news broadcast using a $16 \mathrm{~mm}$ film camera. Establishing shots of cars parked along Main Street and white parishioners leaving church on Sunday helped to introduce the short segment and contrast visually with the chilling footage of the human effigies seen hanging from the flagpole and the entrance to Mansfield High School later in the segment. ${ }^{12}$ Although the footage is silent, the original broadcast script provides context to the imagery: "It's a quiet Sunday in Mansfield, where angry crowds of whites gathered last week to scare off Negroes who planned to enroll in public school. . . . At the school, effigies of Negroes hang above the front door of the school and at the top of the flagpole." 13

Footage like this is powerful in its ability to help people understand the past. Although scholars know that these events took place in Mansfield 60 years ago, no film footage of the demonstrations or of the effigies hung from the high school was known. The pilot project uncovered many more examples of lost historical footage that could potentially be of interest to scholars and community members both in Texas and beyond (see Table 3). The discovery of this footage clearly demonstrates the significance of the NBC 5/ KXAS-TV collection and the importance of preserving such recordings for the future, and it inspired UNT and NBC 5/KXAS-TV to embark on a cooperative plan to publicize the archive project.

Table 3: Sample of Footage Found in 16mm Film Pilot Project

\begin{tabular}{|l|l|}
\hline Date & Segment \\
\hline August 2,1956 & Interview with a Survivor of the Andrea Doria Shipwreck \\
\hline August 13,1956 & $\begin{array}{l}\text { Vice-President Richard Nixon in Dallas, Warns U.S. Losing } \\
\text { Popularity }\end{array}$ \\
\hline August 16, 1956 & W. Lee O'Daniel Announces Run for Governor \\
\hline August 22,1956 & $\begin{array}{l}\text { Announcement that Dallas Public School will Remain Segre- } \\
\text { gated }\end{array}$ \\
\hline September 4, 1956 & Housing Desegregation Protest in Fort Worth \\
\hline
\end{tabular}

\section{NBC 5/KXAS-TV On-Air Promotions}

A successful cooperative partnership must take advantage of each partner's unique skills and abilities. Archivists and librarians at UNT provide expert care, cataloging, and preservation for the archival collection. NBC 5/KXAS-TV fully utilized the talents and abilities of its producers, camera operators, and journalists to assist in the promotion of the archives project, and provided visibility to over seven million people within their viewing area by featuring on-air promotions about the collection. The greatest 
contribution to the project made by NBC 5/KXAS-TV came during the month of January 2015 when the news station featured a week-long series of three- to four-minute promotions on the 6:00 p.m. news, followed by short "break-bumpers" (10- to 15-second promotions between programming and commercials) directing viewers to a page on the station's website created specifically for the promotional videos. These promotional segments were branded as being from the "Video Vault," and the newscasters introduced each promotion with information about the collection, UNT Libraries, and how to find video segments online. The first promotional segment aired on January 12, 2015 (see Figure 1) and was introduced with these words:

Tonight we have a big announcement to share with you. NBC 5 is putting all of our old news film online. This is a unique partnership here with the University of North Texas called the Portal to Texas History. Our parent company NBCUniversal is donating $\$ 275,000$ to make this project happen. It is a Texas-sized commitment to preserving our past. All this week at 6:00 we are opening our video vault. We start this week in the summer of 1956 when big things were already happening in DFW. ${ }^{14}$

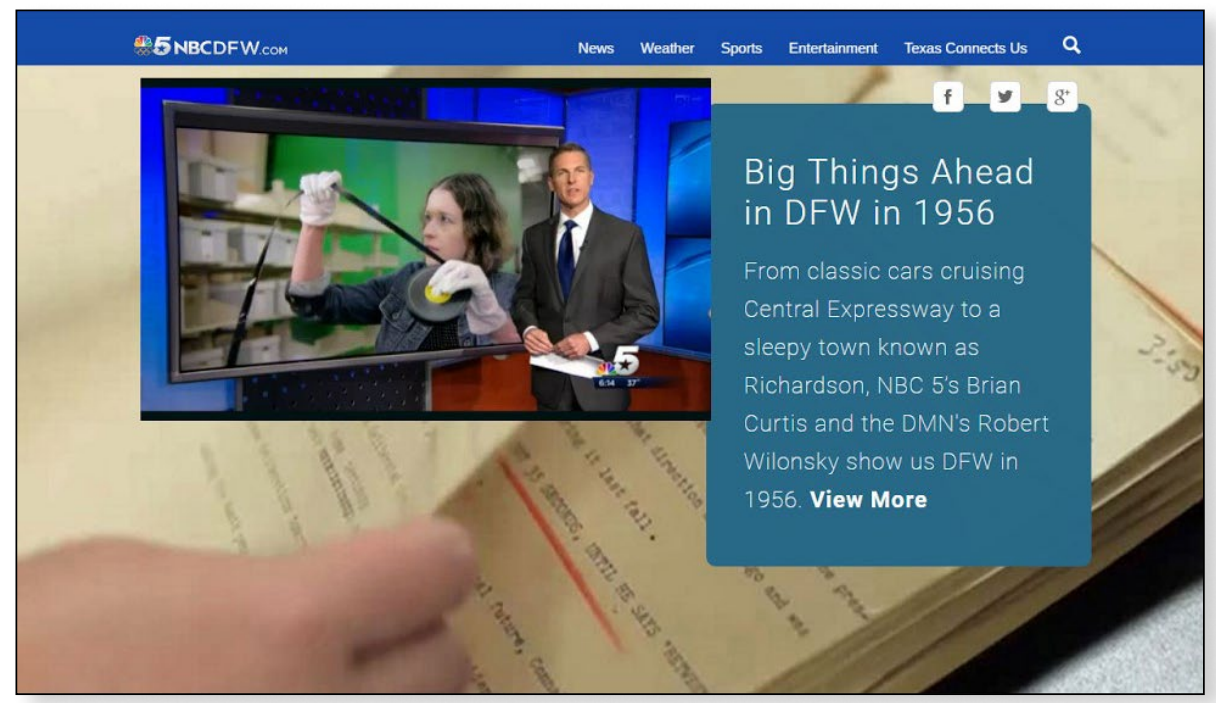

Figure 1: Screen capture from NBC 5/KXAS-TV archive promotion website

In addition to the promotional segments aired during the evening news, NBC 5 invited the head of Special Collections and the dean of Libraries to be guests on its Saturday morning public-affairs television talk show. NBC 5/KXAS-TV also sent crew members to UNT to create a four-minute "sizzle reel," which introduces the archives project, its goals, and the cooperative partnership established between the two institutions. This "sizzle reel" is a quick way to get people interested in the collection and can easily be shared on the UNT website and social media accounts. 


\section{Current Project Status}

Since the project launch in 2015, significant progress has been made to digitize and make the news collection accessible. The U-matic tapes were prioritized for digitization, and over 2,000 tapes have been digitized and edited into over 48,000 individual news segments. A significant number of $16 \mathrm{~mm}$ films have also been digitized as a result of on-demand patron requests. Although patrons generally request a range of one to two days of news film, the archives was able to use external project funding to digitize the entire month of film from which each patron request originated. This system allows a week's worth of film to be compiled onto larger reels, which are more convenient for storage than using individual reels for each day. In 2018, 16mm films from the first two years of broadcast (1951-1952) were targeted for digitization and are currently being prepared. Scanning of the broadcast scripts proved to be a challenging endeavor due to the increasing number of daily broadcasts in the 1960s and 1970s. For this reason, digitization of the scripts has been outsourced to a vendor.

Metadata creation has become a major focus of the project. Metadata is a time-consuming, yet necessary and vital component of any digitization project, and the addition of full-time staff devoted to this important work has allowed UNT to increase its metadata creation capacity. The increased demand for metadata creation has also led to the opening of a Special Collections "metadata suite" in the library; a space with 15 workstations devoted to metadata creation and with room for expansion as new metadata students are hired. There is currently a backlog of 90,919 digitized items (including video, scripts, and photographs) awaiting metadata. ${ }^{15}$

Use of the collection has skyrocketed as new content is added to the Portal to Texas History. As of September 2019, 124,900 items are available online, including 71,000 scripts, 45,716 film and video segments, and 7,545 photographs. Since 2014, these items have been viewed online 1,327,655 times, with over 616,000 of those views occurring in 2018 alone. Average daily usage tops 2,000 page views. The digitization project has also brought highly significant and previously unknown news footage to the public. This includes graphic and disturbing footage of civil rights protest sit-ins at Dallas's Piccadilly Cafeteria in 1964 showing the removal of nonviolent protestors from the cafeteria by police and the protests and picketing that followed. ${ }^{16} \mathrm{In}$ another instance, film footage of a previously unidentified man interviewed at the Texas Gay Conference of 1978 was later confirmed to be gay rights activist and politician Harvey Milk. ${ }^{17}$

The partnership between the news station and the library continues to be positive and productive. In addition to joint fund-raising efforts to support the project, the library helped the news station celebrate its 70th anniversary in 2018 through an online exhibit of newly digitized content. NBC5 used the opportunity of the anniversary to host a fund-raising event attended by community and corporate leaders, at which a new "sizzle reel" incorporating newly digitized news footage from the project was shown. ${ }^{18}$ The station also produced a 30-minute special entitled 70 Years of Innovation, which incorporated many examples of archival media and aired multiple times throughout the year. The special broadcast cleverly linked historical innovation in news production techniques to 
present-day innovations used to digitize and preserve the news archive. ${ }^{19}$ At its current pace, the project is funded for at least the next one to two years, and new fund-raising requests are generated on a regular basis. Fund-raising for the project has been most successful with private foundations, primarily those with a mission to support education and history. Licensing revenue is also expected to make up an increasing percentage of funding for the project.

\section{Toward a Custodial Partnership Model}

Archival literature abounds with descriptions of problems inherent in the institutional collection of archival materials. Archival collecting practices, either consciously or unconsciously, have encouraged a distorted view of history by minimizing the representation of diverse people, communities, and issues. Institutions collect archival materials that only sit unprocessed and inaccessible to the public for decades; while some repositories may completely overlook valuable archival materials created in born-digital formats in favor of paper records. Archivists always seem to be playing catch-up in a changing world. In 1981, the state archivist of Wisconsin, F. Gerald Ham, warned:

Concern with the uniqueness of the material in our care, and the normal expectations of our custodial role, tended to make us uncommonly introspective, preoccupied with our own gardens, and too little aware of the larger historical and social landscape that surrounded us. Our introspective proclivity has isolated us from one another and fragmented our work, obscuring the advantages of cooperation and shared ideas. ${ }^{20}$

This concern expressed by Ham nearly 40 years ago is still very much an issue today. There is too little cooperation between repositories, too little collaboration with outside partners, and too much concern with acquiring distinctive collections for the sake of building an institutional reputation. Ham's response to these concerns was the introduction of the postcustodial approach to collection development. ${ }^{21}$ In his article, Ham urged the archival profession to let go of its custodial mentality and to be open to new ways of acquiring and providing access to records, for the betterment of both the archival profession and the preservation of our collective memory. Ham was especially concerned with electronic records, which can be both a great challenge and a benefit to future archivists, in that they can be easily copied and shared between institutions, and therefore do not require the donor to transfer custody of the records solely to one archival repository.

The Society of American Archivists defines the postcustodial theory of archives as "the idea that archivists will no longer physically acquire and maintain records, but that they will provide management oversight for records that will remain in the custody of the record creators."22 Although this definition seems completely focused on the physical custody of records, most archivists would likely agree that a postcustodial approach to collecting encompasses much more than who has possession of the physical materials. The major themes that have come to define the archival profession's understanding and expectations of the postcustodial era are actually access and cooperation. Since the 1990s, 
postcustodial approaches have focused heavily on electronic archival records, digitization of analog archival records, and distributed physical custody of archival records. ${ }^{23}$ Missing from these discussions, however, is Ham's message that by isolating ourselves from records creators we are "obscuring the advantages of cooperation and shared ideas." ${ }^{24}$

In a 2004 article, Jeanette Bastian emphasized the connection between control (or custody) and access, and pointed out the importance of access to archival records in maintaining collective memory:

Cohesive and reliable construction of collective memory by nations, communities, or groups of people depends upon their ability to access their own historical records in addition to the artifacts, traditions, folk histories, and other memorializations of their pasts. Access therefore is integral to the custody of those records and must be part of any debate about their care and control. ${ }^{25}$

Those who have control can either hinder or encourage and promote access to records. One way communities approach this issue is by maintaining control over their archival records, either fully independent of a traditional archival repository, or with limited archival services provided by professional archivists. The community archives concept is defined as archives collected and maintained by a community group, "either solely or in collaboration with other bodies and individuals including archival and heritage professionals." ${ }^{26}$ Community participation, control, and ownership are central to this concept. The concept of participatory archives is also similarly related. Kate Theimer has defined participatory archives as "an organization, site or collection in which people other than archives professionals contribute knowledge or resources, resulting in increased understanding about archival materials, usually in an online environment." ${ }^{27}$

In working with the news collection, UNT has adopted a different model for negotiating the issues of access, control, and custody through a cooperative partnership: the custodial partnership model. This model is useful in situations where the records creator desires a formal transfer of ownership of physical materials, but is also willing to contribute to a continued relationship with the institution holding the collection. Unlike community archives and participatory archives models, this model takes into account the importance of professional archival institutions to handle and preserve the collection, while also calling upon the records creator to be a long-term partner in the ongoing work necessary to preserve and digitize a collection. Whereas a community or participatory model fits the needs of a specific community of people-especially traditionally underrepresented individuals - by allowing them to maintain control of their history, the custodial partnership model focuses on how the records creator can and should assist in the stewardship of a collection managed within an archival repository. A custodial partnership model is well suited, then, for large collections of corporate or organizational materials, where long-term preservation and digitization costs are a primary concern. The custodial partnership model thus falls in between a traditional custodial model, which emphasizes the transfer of custody, and a postcustodial model, which emphasizes access over ownership (see Figure 2). 


\section{Custodial \\ Custodial Partnership \\ Postcustodial}

Figure 2: Diagram of custodial models showing a diminished emphasis on custody

While audiovisual archives focus primarily on digitization and access, the question of physical custody cannot be ignored, and, for this reason, a fully postcustodial approach may not be appropriate for all types of collections. These are unique materials, and as such, it is essential that the original source be preserved as long as possible. It is well within the realm of expectation that whatever digital surrogates are created today may be surpassed by future advances in technology, in much the same way that a digital surrogate created in 1996 would look very different from one created in 2016. Second, in the time it takes to fully digitize a collection, any number of catastrophes, such as fire, flood, or theft, could irreparably damage or even destroy a collection. While archives are not completely immune to such acts, most have safeguards in place to mitigate these potential threats. Digitized content is also not free from danger. In the event that digital preservation safeguards fail, it may be necessary to return to the original media to access the content. In the case of news content created by a publisher or broadcaster, the custo$\mathrm{dy}$ of the collection takes on additional significance in light of the unpredictable nature of the journalism business. Ownership of a media organization can change overnight, or, in some cases, an organization may suddenly file for bankruptcy. In such a situation, the care of the collection is usually not among the top concerns of those affected by the changes, making a total loss of the collection entirely possible.

\section{Custodial Partnership Model in Action}

The custodial partnership model is a method by which partners may continue to be involved in the life cycle of an archival collection beyond the point of its deposit in a repository. In this example, the partner (NBC 5/KXAS-TV), chose to transfer its collection of physical archival materials to a repository (UNT Libraries), mirroring a traditional custodial approach. The "partnership" aspect of this model refers to the carefully negotiated and ongoing role of the partner in archival decision-making and the mutual, primary goal of making the records widely accessible through large-scale digitization. As a repository, UNT Libraries has made a commitment to providing access to partners' collections and to maintaining supportive, cooperative relationships with record creators and donors long after transfer of their records to the repository. It is this aspect of the partnership that places it squarely within a postcustodial approach, despite the fact that the repository retains physical custody of the records.

The traditional archival donation model is based almost entirely on a single transaction consisting of the transfer of the collection from a donor to a cultural heritage institution via a formal gift agreement. This model has generally been seen as advantageous to the repository because it provides a clear means for the legal transfer of property and places 
no additional burden on the institution accepting the donation. Once a gift agreement has been signed, the archives is not held legally accountable to the donor under most circumstances. While this model succeeds in simplifying the relationship between the donor and the repository in that single transaction, it fails to take advantage of the potential for a longer-lasting, mutually beneficial partnership between the two parties. As suggested in this article, the custodial partnership model has been integral to the success of the NBC 5/KXAS-TV project. Key aspects of the partnership include 1) mutual agreement on the long-terms goals for preservation and access to the collection; 2) good faith efforts on behalf of the donor and repository to raise funds necessary to achieve long-term goals; 3 ) agreement by the archival institution to make reasonable accommodations to facilitate the continuing use of the archive by NBC5/KXAS-TV for business purposes; 4) agreement by the donor to allow reasonable access to the collection, in this case, making the collection freely available in an online streaming format; and 5) granting the archival institution permission to license footage and collect revenue.

Other characteristics of the partnership between UNT and NBC5/KXAS are less formalized, yet no less beneficial. Chief among these characteristics is the willingness of both parties to communicate clearly, openly, honestly, and frequently, which is essential to ensuring that the project is able to overcome obstacles both large and small. During the negotiation period, both UNT and NBC5/KXAS-TV were able to clearly express their needs as well as what support they may be able to offer. While both parties sought to accommodate each other's needs, when something was outside the donor's or repository's capabilities, either was able to say no. This honest communication kept both parties accountable to one another in a reasonable and realistic way. Having these discussions in advance also prevented many problems from developing later. For example, UNT clearly defined the way in which the station should request archival footage for its own future broadcast purposes. The repository established a timeline for how far in advance a request must be made, designated who is responsible for reformatting fees, and created procedures to address situations in which it is unable to digitize footage within the established timeline (e.g., during winter break or other periods when the library is closed for an extended period of time).

\section{Conclusion}

Partnerships such as the one between the UNT Libraries and NBC 5/KXAS-TV can have major benefits for both institutions and the record creators. Often, record creators or the community stewards of a collection have a strong desire for ongoing interaction with the records. They want to ensure that their collections will not just be shelved in a back room and forgotten. Furthermore, they are likely looking to ensure a level of enhanced access to the records beyond which they are currently able to provide. In earlier eras of archival administration, archivists were reluctant to acquire collections with any kind of "strings attached." However, borrowing from the cooperative spirit of the postcustodial approach encourages us to see record creators and community stewards as active participants in archival administration regardless of who becomes the final custodian of the records themselves. In the example shared here, the benefits of the 
partnership for the record creator, NBC 5/KXAS-TV, includes the ability of the station to retain copyright to its content, the validation of being associated with an academic institution, the services and skills of the professional archivists managing the collection, increased access to the collection, and the ability to maintain an active involvement in the archival decision-making process. For the archives, the partnership with NBC 5/ KXAS-TV has allowed UNT to further its mission to preserve historically significant cultural materials. Additionally, partnership with a major news station has provided the library with access promotion, outreach, and fund-raising skills and abilities that would otherwise be far beyond its reach.

\section{ABOUT THE AUTHOR}

Morgan Davis Gieringer is the head of Special Collections at the University of North Texas Libraries and the director of the Graduate Academic Certificate in Archival Management in the UNT College of Information. As head of Special Collections, she oversees major archival initiatives, which include the LGBTQArchive, the NBC5/ KXAS Television News Collection, the Black Academy of Arts and Letters Archive, and the Dallas Area Rapid Transit Archive project. Gieringer's professional interests include the theory and practice of acquisition; new methods of acquisition; and the application of project management techniques to archival processes such as digitization and processing. She is an active member of the Society of Southwest Archivists and participates regularly with the DFW Metroplex archivists and the DFW Archives Bazaar.

\section{NOTES}

1. Charles L. Ponce DeLeon, That's the Way It Is: A History of Television News in America (Chicago: University of Chicago Press, 2015), 5.

2. Wikipedia, s.v. “Amon G. Carter," last modified September 26, 20019, https://en.wikipedia.org/ wiki/Amon_G._Carter.

3. NBC5-KXAS-TV, “The History of Channel 5," last modified October 5, 2018, http://www.nbcdfw .com/on-air/about-us/The_History_Of_Channel_5.html.

4. Chris Van Horne, "NBC Breaks Ground on New Facility," NBC5-KXAS-TV, July 29, 2012, https:// www.nbcdfw.com/the-scene/real-estate/NBC-5-Breaks-Ground-on-New-Facility-160897765 .html.

5. DeLeon, That's the Way It Is, 12 .

6. Ibid., 6

7. J. Fred MacDonald Newsreel Collection, Library of Congress, Washington, DC, United States (Note: finding aid only available upon request from the LOC National Screening Room).

8. [News Script: Horse rescued], KXAS-NBC 5 News Collection, January 12, 1951, The Portal to Texas History, University of North Texas Libraries, https://texashistory.unt.edu/ark:/67531/ metadc700447.

9. NBC Log Books, KXAS-NBC 5 News Collection, The Portal to Texas History, University of North Texas Libraries, https://texashistory.unt.edu/search/?fq=str_title_serial:NBC\%20Logbooks.

10. NBC News Scripts, KXAS-NBC 5 News Collection, The Portal to Texas History, University of North Texas Libraries, https://texashistory.unt.edu/search/?fq=str_title_serial:NBC\%20News\%20 Scripts\&src=ark. 
11. George N. Green, "Mansfield School Desegregation Incident," Handbook of Texas Online, http:// www.tshaonline.org/handbook/online/articles/jcm02.

12. [News Clip: New Racial Strife in Fort Worth; Mansfield], September 2, 1956, The Portal to Texas History, University of North Texas Libraries, https://texashistory.unt.edu/ark:/67531/ metadc307692.

13. [News Script: Mansfield], September 2, 1956, The Portal to Texas History, University of North Texas Libraries, https://texashistory.unt.edu/ark:/67531/metadc306291/.

14. NBC5-KXAS-TV, "The Portal to Texas History," http://www.nbcdfw.com/profiles/local/ DFWThe-Portal-to-Texas-History-287968361.html.

15. "Statistics: KXAS-NBC-5 News Collection," The Portal to Texas History, https://texashistory.unt .edu/explore/collections/KXAS/stats/.

16. [News Clip: Demonstrators], May 30,1964, The Portal to Texas History, University of North Texas Libraries, https://texashistory.unt.edu/ark:/67531/metadc1062741.

17. [News Clip: Gay (Rights conference)], June 10, 1978, The Portal to Texas History, University of North Texas Libraries, https://texashistory.unt.edu/ark:/67531/metadc1083659.

18. [NBC 5 \&UNT Archive 2018 Sizzle Reel], 2018, The Portal to Texas History, University of North Texas Libraries, https://texashistory.unt.edu/ark:/67531/metadc1334166.

19. NBC5-KXAS-TV, 70 Years of Innovation on NBC 5, October 5, 2018, https://www.nbcdfw.com/ news/local/70-Years-of-Innovation_Dallas-Fort-Worth-495299931.html.

20. F. Gerald Ham, "Archival Strategies for the Post-Custodial Era," American Archivist, 44, no. 3 (1981): 207.

21. Ibid., 207-16.

22. Richard Pearce-Moses, A Glossary of Archival and Records Terminology (Chicago: Society of American Archivists, 2005), 302, http://files.archivists.org/pubs/free/SAA-Glossary-2005.pdf.

23. Sofia Becerra-Licha, "Participatory and Post-Custodial Archives as Community Practice," EDUCAUSE Review, October 23, 2017, https://er.educause.edu/articles/2017/10/participatoryand-post-custodial-archives-as-community-practice. Hannah Alpert-Abrams, "Post-Custodial Archiving for Our Collective Good," CLIR News, October 25, 2018, https://www.clir.org/2018/10/ post-custodial-archiving.

24. Ham, "Archival Strategies for the Post-Custodial Era," 207.

25. Jeannette Allis Bastian, "Taking Custody, Giving Access: A Postcustodial Role for a New Century," Archivaria 53 (2004): 76-94.

26. Luciana Duranti and Patricia C. Franks, eds., Encyclopedia of Archival Science (Lanham, MD: Rowman \& Littlefield), 147.

27. Kate Theimer, "Exploring the Participatory Archives: Why, What, Who, Where, and Why" (presentation, Society of American Archivists Annual Meeting, August 25, 2011), https://www .slideshare.net/ktheimer/theimer-participatory-archives-saa-2011. 